\title{
USE OF UNIDIRECTIONAL BARBED SUTURE IN GYNECOLOGIC LAPAROSCOPIC SURGERY
}

\author{
Fatih SENDAG, Levent AKMAN
}

Department of Obstetrics and Gynecology, Ege University, Faculty of Medicine, Izmir, Turkey

\section{SUMMARY}

With the developments in technology, lots of innovations were brought into the use of medical society. Suture material including barb technology (V-Lock) is one of them and it is important for doctors who have limited experience in laparoscopic intracorporeal knot tying. In this article; the advantages and disadvantages of this useful absorbable suture material and its utilization in laparoscopic operations will be mentioned.

Key words: barb, intracorporeal knotting, laparoscopy

Journal of Turkish Society of Obstetrics and Gynecology, (J Turk Soc Obstet Gynecol), 2013; Vol: 10, Issue: 3, Pages: 187- 90

\section{JINEKOLOJIK LAPAROSKOPIK CERRAHIDE TEK YÖNLÜBARBED SÜTUR}

\section{ÖZET}

Gelişen teknolojiyle birlikte birçok yenilikler tıbbın hizmetine sunulmuştur. Barb teknolojisi içeren sutur materyali (V-Lock) bunlardan bir tanesidir ve intrakorporal düğ̈̈m atma deneyimine sahip olmayan doktorlar için önemli bir materyaldir. Makalede, absorbabl ve kullanışlı bu sutur materyalinin laparoskopik işlemlerde kullanımı, avantajları ve dezavantajlarını göz önünde bulunduracă̆ız.

Anahtar sözcükler: barb, intrakorporal düğ̈̈m, laparoskopi

Türk Jinekoloji ve Obstetrik Derneği Dergisi, (J Turk Soc Obstet Gynecol), 2013; Cilt: 10, Sayl: 3, Sayfa: 187-90

\section{INTRODUCTION}

In laparoscopic surgery, suturing and intracorporeal knot tying require an important amount of experience. With the developments in technology, several solutions have been proposed to help reduce the stress on surgeons. Although an inseparable component of surgery, the suture materials, were developed greatly, the perfect suture is yet to be introduced. Major facilitating solutions are easy knot tying techniques, clips which could replace knot tying and suture materials that don't require knot tying.

One of these solutions, Barb technology, has microscopic etching which allows self-anchoring without the need of knots. Unidirectional and bidirectional barbed suture options are available. Vlock is a unidirectional polyglyconate suture material armed with a loop at one end and a needle at the other end. Loop design is secured without the need of to knot tying by passing the needle through (Figure 1,2). The monofilament, synthetic material hydrolyzes within 180 days and tissue tension is maintained for about a month. It is attached to each mm of the tissue on its own and provides a more evenly distributed tension than the conventional smooth suture along the suture line. End result is a knotless suture line.

\footnotetext{
Address for Correspondence: Dr. Levent Akman. Ege Üniversitesi Tıp Fakültesi, Kadın Hastalıkları ve Doğum Anabilim Dalı, 35100 İzmir Phone: + 90 (532) 4623009

e-mail: leventakman@gmail.com

Received: 16 April 2012, revised: 16 April 2012, accepted: 17 October 2012, online publication: 17 October 2012
} 


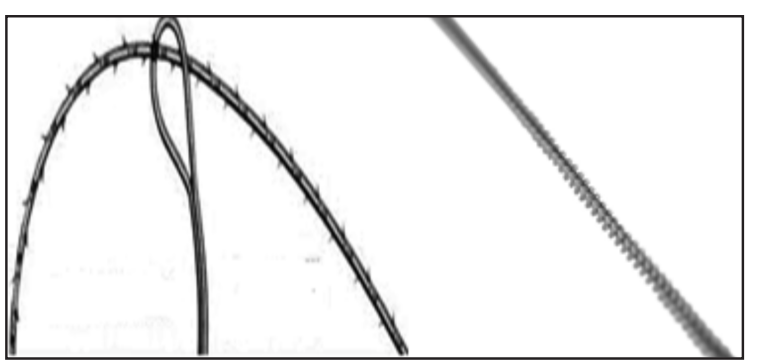

Figure 1: Barbed structure and loop design of the unidirectional barbed suture.

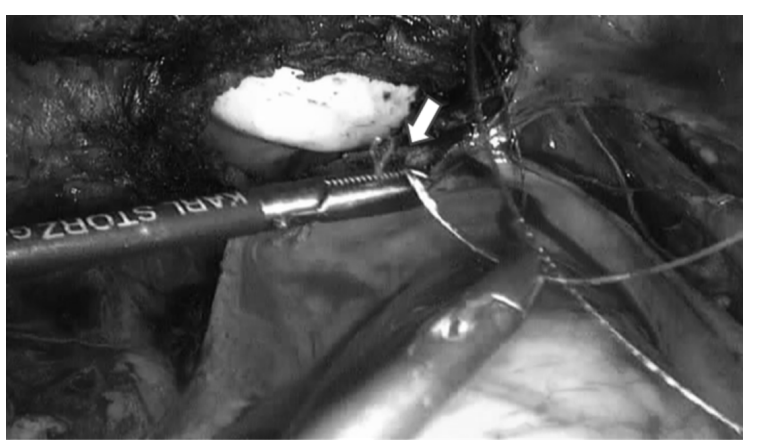

Figure 2: Needle passing through the loop (arrow) in closure of vaginal cuff.

Knot tying experience required for laparoscopic surgery is hard to obtain. This condition stresses the surgeon during knot tying ${ }^{(1,2)}$. In the closure of vaginal cuff, surgeons, especially the ones who have limited experience in intracorporeal knot tying prefers extracorporeal knot tying or vaginal suturing. This skill can be acquired through long and patient practice.

In a surgical procedure, a knotless suture line might seem unsecured at first. However, the conventional knot and the loss of tensile strength around the knot is not present in barbed suture ${ }^{(3)}$. Besides, a study comparing the smooth suture to barbed suture in closure of swine gastrointestinal system showed no difference between the burst strength pressures ${ }^{(4)}$. Barbed suture material frequently had applications such as laparocopic closure of vaginal cuff and myomectomy procedures in gynecologic surgery. Data about pfanensteil incision suturing is present as well.

In gynecologic surgery, vaginal cuff dehiscence following laparoscopic vaginal cuff closure is a rare but important complication. It is necessary to acknowledge significant points to reduce the risks. First of all, bacterial contamination of the vaginal cuff causes febrile morbidity. Furthermore; this contamination might cause cellulitis of the vaginal cuff and pelvic abscess. For these reasons, suture material that will minimize the bacterial growth should be chosen while closing the vaginal cuff. Besides, external factors the cuff might be exposed to during healing process (increase in intra abdominal pressure, sexual intercourse) should be considered. Also, thermal energy used for entering the vagina during laparoscopy causes delay in healing of the wound edges ${ }^{(5,6)}$. Therefore, in the closure of vaginal cuff, material that is more elastic and that maintains the tension force for a longer period should be preferred.

Siedhoff et al. (7) retrospectively compared the bidirectional barbed sutures to other closure techniques in laparoscopic closure of the vaginal cuff following hysterectomy or trachelectomy. First year follow-up results revealed $4.2 \%$ dehiscence in other closure techniques while none was noted with barbed suture $(\mathrm{p}=0.008)$. In addition, postoperative bleeding, granulation tissue formation and cellulitis occurred more frequently in other techniques.

Mymectomy is another gynecologic procedure where barbed suture is frequently used. Due to severe blood loss that could occur during myomectomy, fast bleeding control and a secure suture line are essential. Einarson et al. ${ }^{(8)}$ applied barbed suture to 107 and conventional smooth suture to 31 patients following laparoscopic myomectomy. Average length of the surgical procedure has been found to be significantly shorter with barbed suture (118 vs 162 minutes, $\mathrm{p}<0.05$ ). Shorter hospital stay duration was noted in barbed suture group as well (0.58 vs $0.97, \mathrm{p}<0.05)$. However, perioperative complications, blood loss or number of myomas did not differ significantly. Alessanri et al. ${ }^{(9)}$ also compared the knotless barbed suture to continuous suture and intracorporeal knot tying during laparoscopic myomectomy. Barbed suture closure revealed significantly lower numbers for uterin wall closure duration (11.5 \pm 4.1 vs $17.4 \pm 3.8, \mathrm{p}<0.001)$, blood loss during the procedure $(\mathrm{p}<0.001)$ and degree of surgical difficulty $(p<0.001)$. However operative time did not differ between the two groups. Einarsson et al.(10) mentioned in another study that barbed suture material can even be utilized in single incision laparoscopic myomectomy for intramural myomas. It is noted that, since barbed suture does not require a knot, difficult steps are greatly facilitated, perfect tension is provided and advantages should be evaluated with prospective research. Studies that asses the adhesion formation in sheep myometrium at 3 months ${ }^{(11)}$ showed no difference between barbed suture and polyglactin 210 
(Vicryl) $(52.2 \%$ vs $\% 43.5, \mathrm{p}>0.05)$.

Apart from the laparoscopic applications, barbed sutures have been utilized in closure of Pfanensteil incisions as well. Naki et al. ${ }^{(12)}$ compared the barbed suture to poliglecaprone and stapler in closure of Pfanensteil incisions performed for benign gynecological procedures. Incision length, undesired impact (dehiscence, infection, seroma, hematoma), pain and cosmetics scores were found out to be similar for three groups. Murtha et al. ${ }^{(13)}$ compared the barbed suture to 3-0 Polydioxanone in closure of Pfanensteil incision and found cosmetic results and security profile to be similar to conventional method. Authors noted that risks such as the ischemia caused by tight knots, focus of infection with big knots, protrusion at wound site and needle penetrating the gloves can be avoided by using barbed sutures.

No human data is available for application of barbed suture in caesarean sections. Greenberg et al. ${ }^{(14)}$ found polyglecaprone 25 to be adequate for closure of uterus in pregnant sheep model following caeserean section and considered it as an equivalent to both chromic and polyglactine 910 absorbable sutures.

Ultimate advantage of the barbed suture is that it allows the inexperienced surgeon to complete the procedure easily and speeds up the process. From a surgical standpoint, material; given its monofilament structure, reduces the local inflammation and risk of infection ${ }^{(3)}$ Due to thornlike etching, it is attached to the each millimeter of the tissue providing both, hemostasis and an even distribution of tension across the wound. Granulation tissue formation following a vaginal cuff closure procedure with chromic catgut is an undesired outcome $^{(15)}$. It might be advisable to utilize barbed suture instead of polyglactine 910 which is absorbed earlier, because of the slow healing at vaginal cuff due to thermal energy used for entering the vagina and increased risk of dehiscence ${ }^{(3)}$. Long term tissue support and decrease in granulation formation risk make barbed suture a likely candidate even in a thermal damage setting. Laparoscopic knots are relatively weaker next to robotic or manual $\operatorname{knots}^{(16)}$. Due to its thornlike structure, barbed suture resists migration by anchoring tightly.

Cuff dehiscence risk of other suture material applies to barbed suture as well. Since a knotless continuous suture line is formed after the procedure, a gentle traction should be applied to the middle of the wound to make sure barbs are effective. As the suture cannot be withdrawn, in case a rupture occurs, a new suture should be put to use to resume. Also, presence of a long term suture material within the tissue might cause discomfort during sexual intercourse.

In our clinic, we utilized V-Lock suture material in laparoscopic hysterectomy, total laparoscopic hysterectomy (Figure 3) and laparoscopic myomectomy procedures. Suture material provided facilitation and speed, especially for myomectomy and single port operations. No vaginal cuff dehissence was noted in follow up. Surgeons must be aware of the complications that might arise from the technological innovations. There are published cases of small bowel obstruction as an adverse effect following vaginal cuff closure with barbed suture ${ }^{(17)}$. However, it must be noted that the aforementioned problem could be the result of excess suture material measuring 4 centimeters as explained in the article ${ }^{(18)}$. Data obtained so far confirms that knotless suture material facilitates laparoscopic suturing and speeds up the procedure. Further research shall extend the applications of this practical and costeffective material.

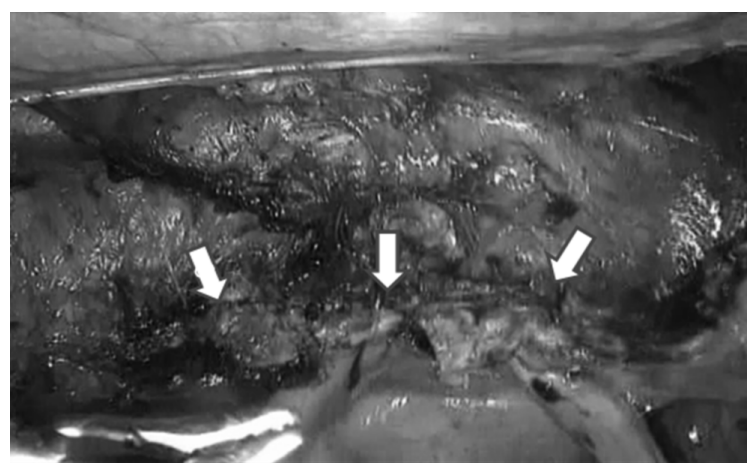

Figure 3: View of the vaginal cuff following closure with unidirectional barbed suture.

\section{REFERENCES}

1. Berguer R, Smith WD, Chung YH. Performing laparoscopic surgery is significantly more stressful for the surgeon than open surgery. Surg Endosc. 2001; 15: 1204- 12.

2. Berguer R, Chen J, Smith WD. A comparison of the physical effort required for laparoscopic and open surgical techniques. Arch Surg. 2003; 138: 967- 70.

3. Greenberg JA. The Use of Barbed Sutures in Obstetrics and Gynecology. Rev Obstet Gynecol. 2010; 3: 82- 91.

4. Demyttenaere SV, Nau P, Henn M, et al. Barbed suture for 
gastrointestinal closure: a randomized control trial. Surg Innov. 2009; 16: 237- 42 .

5. Sowa DE, Masterson BJ, Nealon N, von Fraunhofer JA. Effects of thermal knives on wound healing. Obstet Gynecol. 1985; 66: 436- 9 .

6. Hur HC, Guido RS, Mansuria SM, et al. Incidence and patient characteristics of vaginal cuff dehiscence after different modes of hysterectomies. J Minim Invasive Gynecol. 2007; 14: 311- 7.

7. Siedhoff MT, Yunker AC, Steege JF. Decreased incidence of vaginal cuff dehiscence after laparoscopic closure with bidirectional barbed suture. J Minim İnvasive Gynecol 2011; 18: $218-23$

8. Einarson JI, Chavan NR Suzuki Y, et al. Use of birectional barbed suture in laproscopic myomectomy : evaluation of perioperative outcomes, safety, and efficacy. J Minimal İnvasive Gynecol 2011; 18: 92- 5.

9. Alessanri F, Remorgida V, Venturini PL, et 1. Unidirectional barbed suture versus continuous sutre with intracorporeal knots in laparoscopic myomectomy: a randomized study. J Minimal İnvasive Gynecol 2010; 17: 725- 9.

10. Einarsson JI. Single incision laaroscopic myomectomy. J Minimal İnvasive Gyncol 2010; 17: 371- 3.

11. Einarson JI, Grazul -Bilska AT, Vonnahme KA. Barbed vs standart suture: randomized single-blinded comparison of adhesion formation ans ease of use in animal model. J Minim
İnvasive Gynecol 2011; 18: 716- 9.

12. Naki MM, Api O, Acioglu HC, Ozkan S, Kars B, Unal O. Comparative study of a barbed suture, poliglecaprone and stapler in Pfanensteil incisions performed for benign gynecological procedures: a randomized trial. Acta Obstet Gynecol Scand. 2010; 89: 1473- 7.

13. Murtha AP, Kaplan AL, Paglia MJ, et al. Evluation of a novel technique for wound closure using a barbed suture. Plast Reconstr Surg 2006; 117: 1769- 80.

14. Greenberg JA, Walden S, Hammer CM, Grazul-Bilska AT, Vonnahme KA.A comparison of barbed and smooth sutures for ovine cesarean delivery. Int J Gynaecol Obstet. 2011; 113 : 215- 7 .

15. Manyonda IT, Welch CR, McWhinney NA, Ross LD. The influence of suture material on vaginal vault granulations following abdominal hysterectomy. Br J Obstet Gynaecol. 1990; 97: 608- 12 .

16. Kadirkamanathan SS, Shelton JC, Hepworth CC, et al. A comparison of the strength of knots tied by hand and at laparoscopy. J Am Coll Surg. 1996; 182: 46- 54.

17. Donnellan NM, Mansuria SM. Small bowel obstruction resulting from laproscopic vaginal cuff closure with a barbed suture. J Minim İnvasive Gynecol 2011; 18: 528- 30.

18. Greenberg JA. Letter to the editor. J Minimal İnvasive Gynecol, 2012; 19: 134 